\title{
Review of Potato Value Chain Performance in Ethiopia: Financial Value Addition and Margin Sharing Perspective
}

\author{
Abayneh Feyso Ergetew \\ (MSc. In Agribusiness and Value Chain Management) \\ Lecturer at Arba Minch University College of Agricultural Science, Arba Minch, Ethiopia \\ abay.fa2014@gmail.com
}

\begin{abstract}
Potato is among the major root and tuber crops and share $41.14 \%$ of area coverage and $29.9 \%$ of total production. Almost all improved potato varieties released in Ethiopia mature within 124 days, which made potato shorter crop cycle among horticultural crops and is regarded as food security crop in Ethiopian. Around $80 \%$ of potatoes are sold as ware tubers and $85 \%$ of them is consumed fresh. Each potato consumers have their own quality criteria to purchase potato. To fulfill these consumers preference all chain actors expected to coordinate and collaborate along the chain. This review article was done to review value chain performance of potato in Ethiopia from financial performance perspective. Specifically, it aim to review potato value chain actors and their role, actors value additions and profit share along chain and to recommended leverage point to upgrade potato value chain in Ethiopia. To came up with well-organized review result, empirical studies conducted in potato value chain in Ethiopia for different purpose, published documents and value chain research guide books were reviewed systematically. To determine performance analysis of potato value chain in Ethiopia, financial perspective of percentage value added along the chain and value share by each chain actors were used and comparisons were held. Review results indicate that compared to producer farmers, traders adding low cost margins and sharing market margin and profit margin. Tariff setting and fixing responsibility of brokers, establishment of well-organized market information system and functional upgrading of producers recommended improve potato value chain performance in Ethiopia.
\end{abstract}

Key words: Value chain, Ethiopia, potato, actors and performance analysis

\section{Introduction and Justification}

Value chain is the full range of activities which are required to bring a product or service from conception, through the different phases of production, transformation and delivery to final consumers (Kaplinsky and Morris, 2000; Joshi and Gurung, 2009). To perform range of activities; number of economic actors are expected to participate along the chain. The value chain approach starts at an understanding of the consumers demand and works its way back through distribution channels to different stages of production, processing and marketing (Getachew, 2015). A particular stage in a value chain may affect and be affected by the stage before or after it (Anandajayasekeram and Berhanu, 2009). Promotion of value chains in agribusiness aims to improve the competitiveness of agriculture in national and international markets and to generate greater value added within the country or region (GTZ, 2006). Thus, performance of agricultural value chain depends on how well the actors in the chain are organized and coordinated. Vertical coordination tends to increase in agribusiness systems as innovation requires vertical coordination (Humphrey, 2005). Due to flexibly nature of value chain analysis; it could be conducted for a variety of purposes (USAID, 2008). The analysis of these value chain structures answers a set of questions like how does the production process take place?, who participates at which stage?, where do the different stages take place?, how are they linked, who has which 
benefits? (Kodigehalli, 2011). Also helps to seeks to identify long-term solution to reduce the vulnerability of developing countries to fluctuating world market prices or trade shocks (USAID, 2008). Basic characteristics of value chain are market-focused collaboration: different business enterprises work together to produce and market products and services in effective and efficient manner to respond by living production, processing and marketing activities to market demand (Getachew, 2015).

Potato can be grown on about $70 \%$ of the arable land areas of Ethiopia (Hirpa et. al. 2010). Potato (Solanum tuberosum L.) is considered as food security crop in Ethiopian; because of its ability to provide a high yield and high-quality product per unit input with a shorter crop cycle, among horticultural crops (Adane.et.al, 2010 ). Around $80 \%$ of potatoes are sold as ware tubers and $85 \%$ of them is consumed fresh (Lemaga, 2010). In Ethiopia potato is commonly consumed in the form of cooked potato in a variety of traditional dishes at household level and also some restaurants and big hotels have French fries on their menu (AgroBIG, 2016), while potato consumers have their own quality criteria to purchase potato. According to Awoke and Molla (2018) potato consumers in Ethiopian prefer medium size potato with smooth skin, fresh, red color and free from any physical damage. Therefore, the aim of this article is to review value chain performance of potato in Ethiopia. Specifically, it aim to review potato value chain actors and their role, value additions and profit share along chain and to recommended leverage point to upgrading potato value chain.

\section{Methodology}

This review article is prepared by reviewing and referring different empirical studies conducted in potato value chain in Ethiopia for different purpose, published documents, value chain research guide books, and Ethiopian central statistics agency (CSA) bulletins, international journals and proceedings.

Strong side of this review article is wide geographical area coverage and reviewed recent empirical studies on specific commodities (potato) throughout Ethiopia. The author believes that reviewing studies conducted throughout the country helps to bring information for concerned bodies to intervene and update the chain easily because this article could serve as all in one shop concerning potato value chain in Ethiopia. Whereas, limitations of this paper is that absence of collecting primary data and focused on empirical review because paper missed to analyze directly collected data.

\section{Review Results and Discussion}

\section{Potato production and producers in Ethiopia}

In Ethiopia, Root crops like potatoes, sweet potatoes and taro are among the list of major food crops that are consumed across the country (CSA, 2019). Potato is among the major root and tuber crops. Data over the period of 2014-2019 from the Central Statistical Agency (CSA) show that potato covers about $41.14 \%$ of the total area allocated to root and tuber crops and accounts for $29.9 \%$ of total production. Also several improved potato varieties were released to farmers with improved management practices. These varieties often mature within about 124 days and are characterized by high yields and biotic and abiotic stress tolerances. However, the uptake of these potato varieties and their recommended management attributes by smallholder farmers are very low (AgroBIG, 2016).

Table 1: Area, production and yield of crops for private peasant holdings for Meher season 2014/15 to 2018/19

\begin{tabular}{|c|c|c|c|c|c|c|}
\hline Year & $\begin{array}{c}\text { Number of } \\
\text { Holders }\end{array}$ & $\begin{array}{c}\text { Area } \\
\text { In Hectares }\end{array}$ & $\begin{array}{c}\text { \% of area } \\
\text { covered }\end{array}$ & $\begin{array}{c}\text { Production } \\
\text { In Quintals }\end{array}$ & $\begin{array}{c}\text { \% share of total } \\
\text { production }\end{array}$ & $\begin{array}{c}\text { Yield } \\
(\mathrm{Qt} / \mathrm{ha})\end{array}$ \\
\hline $2014 / 15$ & $1,379,115$. & $70,131.32$ & 32.81 & 9432334.43 & 23.59 & 134.5 \\
\hline $2015 / 16$ & $3,705,879$ & $226,428.84$ & 81.74 & $26,911,691.98$ & 83.66 & 118.85 \\
\hline $2016 / 17$ & $1,197,018$ & $66,923.33$ & 29.21 & $9,214,031.85$ & 19.90 & 137.68 \\
\hline
\end{tabular}


REVIEW OF POTATO VALUE CHAIN PERFORMANCE IN ETHIOPIA: FINANCIAL VALUE ADDITION AND MARGIN SHARING PERSPECTIVE

\begin{tabular}{|c|c|c|c|c|c|c|}
\hline $2017 / 18$ & $1,127,467$ & $69,610.81$ & 29.84 & $9,689,696.44$ & 21.24 & 139.20 \\
\hline $2018 / 19$ & $1,256,696$ & $73,677.64$ & 32.09 & $10,444,363.59$ & 1.05 & 141.76 \\
\hline
\end{tabular}

Source: Own computation based on CSA time serious data, 2020

As CSA time series data summary result (Table 1) shows that among horticultural crops cultivated in Ethiopia potato share the largest percentage. Also as indicated in (Figure 1), except average yield other parameters not show uniform increment and decrement. Area coverage in 2014/15 is less than 2015/16, but from 2016/17 to 2018/19 shows little increment. Average yield per hectare is increasing from year to year this may due to farmers' experience of using recently released improved potato varieties, while theses varieties yield may be better than the old varieties and also it may happened due to strong agricultural experts' efforts of extension service provision and training of farmers about appropriate input use. Study conducted by Addisu (2016) shows that $54.2 \%$ producers used improved varieties while $23.3 \%$ both improved and local varieties. Percentage share of potato area coverage from production year 2014/15 to 2018/19 is decreasing from year to year, this might occur due to low profit sharing of potato, climate change impact, perishability of tuber and crops.

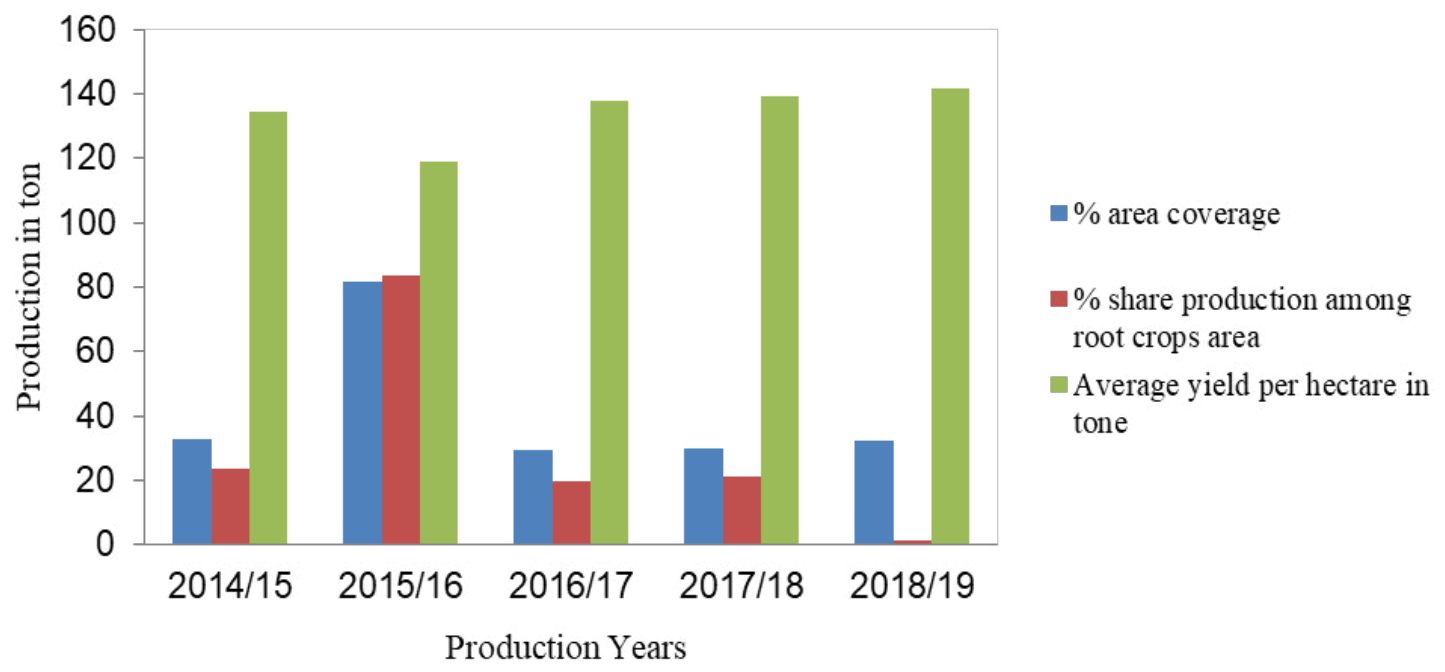

Figure 1: Potato area coverage, production share among root crops, 2020

Source: Own computation based on CSA time serious data

\section{Potato Value Chain Actors and Their Role}

Potato value chain actors are classified as those individuals who take ownership of a product, through the exchange of money or equivalent goods or services, during the transaction process of moving the product from conception to the end user. The primary actors in a potato value chain are seed and other input suppliers; farmers; traders; brokers; processors; retailers; and consumers. Each of these actors adds value in the process of changing product title (Bezabih and Mengistu, 2011; Atetwe, 2016; Getachew, 2015; Habtamu, 2015; Addisu, 2016; AgroBIG. 2016; Tadesse B, and Fayera B,2018; Kabeto, 2019). Second groups of potato value chain actors are service providers. Potato value chain service providers are those individuals or firms providing a service without taking ownership of the product. According to studies conducted in different parts of Ethiopia; potato value chain service providers are Agricultural research centers, agricultural extension service providers offices at different level from ministry to Kebele level office, higher educational institutions, Irrigation development Authority, Trade and Market Development Office, Cooperatives offices, credit and saving institutions and NGOs (Bezabih and Mengistu, 2011; Addisu, 2016; Awoke and Molla, 2018; Tadesse. B. and Fayera. B, 2018; Kabeto, 
2019). Some service providers extend services beyond one function and others are limited to a specific function (Kabeto, 2019)

Table 2: Summary of potato value chain actors and their respective roles along chain

\begin{tabular}{|c|c|c|}
\hline Stage & Specific entities & Roles along the chain \\
\hline $\begin{array}{l}\text { Potato } \\
\text { Input } \\
\text { suppliers }\end{array}$ & $\begin{array}{l}\text { Bureau of Agriculture, Agricultur- } \\
\text { al Research Centers, district agricul- } \\
\text { ture, seed multiplying centers, pri- } \\
\text { vate traders, cooperatives, informal } \\
\text { farmers and producer themselves }\end{array}$ & $\begin{array}{l}\text { Provide improved and local potato seeds, fertilizers, pesticides, } \\
\text { herbicide chemicals, farm implements and labor. }\end{array}$ \\
\hline Potato producers & $\begin{array}{c}\text { Two categories of farmers were no- } \\
\text { ticed : subsistence farmers and } \\
\text { investors and primary producers' } \\
\text { cooperatives }\end{array}$ & $\begin{array}{l}\text { Land preparation, growing/planting/, fertilization, ir- } \\
\text { rigating, protecting from weed, pest/disease, harvest- } \\
\text { ing and post harvest handling and marketing and marketing. }\end{array}$ \\
\hline $\begin{array}{l}\text { Potato } \\
\text { local } \\
\text { collectors }\end{array}$ & Farmer traders & $\begin{array}{c}\text { Collect potato seed tuber from farmers in village markets and } \\
\text { farm gate for the purpose of reselling it to wholesalers and } \\
\text { consumers. Play key role of diffusion of potato seed tuber from } \\
\text { farmer to farmers in the value chain. }\end{array}$ \\
\hline $\begin{array}{l}\text { Brokers/ } \\
\text { middle men }\end{array}$ & Individuals & $\begin{array}{l}\text { Facilitate transaction by convincing farmers to sale his } \\
\text { potatoes and facilitating the process of searching good quality } \\
\text { and quantity potato to wholesalers. } \\
\text { Sometimes go beyond facilitation of transaction and set prices } \\
\text { and make extra benefits from the process. }\end{array}$ \\
\hline Potato Wholesalers & $\begin{array}{l}\text { Individuals traders and cooperative } \\
\text { unions }\end{array}$ & $\begin{array}{l}\text { Mostly buy potato tuber from farmers and collectors in larger } \\
\text { volume and supplying it to traders who come outside the } \\
\text { district and consumers either from outside of the district or } \\
\text { inside the district purchase from farmers and local collectors. }\end{array}$ \\
\hline Potato processing & $\begin{array}{c}\text { Are small scale traders nearer mar- } \\
\text { kets, Street vendors, Supermarkets, } \\
\text { Cafeteria }\end{array}$ & $\begin{array}{l}\text { Buy raw potato from producers, wholesalers, or retail- } \\
\text { ers and sell processed potato (chips, tibs \& cooked) for con- } \\
\text { sumers at street or inside their restaurants. }\end{array}$ \\
\hline Potato Retailers & $\begin{array}{c}\text { Retailers were traders without } \\
\text { license. There are two types of re- } \\
\text { tailers; district retailers and central } \\
\text { retailers }\end{array}$ & $\begin{array}{l}\text { District retailers are buying potato either from farmers or } \\
\text { wholesalers, while central (urban) retailers in major cities } \\
\text { mostly they buy from wholesalers and sell to urban consumers } \\
\text { and also offer potato according to requirement and purchasing } \\
\text { power of the consumer. }\end{array}$ \\
\hline Potato consumers & $\begin{array}{l}\text { Four types of potato consumers } \\
\text { were identified: households, restau- } \\
\text { rants, cafés, and institutions which } \\
\text { give services such as higher educa- } \\
\text { tion institutions, hospitals, etc }\end{array}$ & $\begin{array}{l}\text { Purchase potato product from producers, retailers and } \\
\text { processors. Majority of consumers preferred smooth white, } \\
\text { medium size and undamaged potato and followed by large } \\
\text { size and clean potato. Restaurants, hotels and cafes preferred } \\
\text { larger size, dry and undamaged potato. }\end{array}$ \\
\hline
\end{tabular}

Source: Review of different studies conducted in potato value chain in Ethiopia, 2020

\section{Potato Value Addition and Actors Profit Share along the Chain}

As a product moves from the producer to the consumer, a number of transformations and transactions take place along a chain of interrelated activities, and value is added successively at each stage of the chain (Lilian. et.al.2011). Value added may be related to quality, costs, delivery times, delivery flexibility, innovativeness, etc. The size of value added is decided by the end-customer's willingness to pay (Kaplinsky and Morris, 2002; FAO, 2006; GTZ, 2007; Stevenson and Pirog, 2013). Value added is produced in value chains aiming at certain markets and constituting a number of actors (Trienekens, 2011). Value occurs when needs are met through the provision of products, resources, or services (Andrew. et.al. 2006). Thus, under this sub title potato value 
adding activities performed by different chain actors at different stages and shares of values (marketing margin distribution) at different stages were reviewed.

Table 3: Summary of value addition and form utility brought to end consumers

\begin{tabular}{|c|c|c|c|}
\hline $\begin{array}{l}\text { Stages of } \\
\text { chain }\end{array}$ & Chain actors & Value adding activities & $\begin{array}{l}\text { Utility delivered to } \\
\text { end consumers }\end{array}$ \\
\hline Input supply & $\begin{array}{l}\text { Agriculture offices, seed multiply- } \\
\text { ing centers, private traders, coop- } \\
\text { eratives, NGOs and farmers }\end{array}$ & $\begin{array}{l}\text { Provide potato seeds, fertilizers, chemicals pes- } \\
\text { ticides and herbicide based on demand of pro- } \\
\text { ducers }\end{array}$ & $\begin{array}{l}\text { Place, time and pos- } \\
\text { session utility. }\end{array}$ \\
\hline Production & $\begin{array}{l}\text { Producers (Substance farm- } \\
\text { ers and small scale investors }\end{array}$ & $\begin{array}{l}\text { ploughing, planting, fertilization, digging, weed- } \\
\text { ing and post harvesting handling activi- } \\
\text { ties like sorting out damaged and deteriorated } \\
\text { once, adjusting the storage to sun light, storing, } \\
\text { transporting, loading and unloading which de- } \\
\text { creases }\end{array}$ & $\begin{array}{l}\text { Time utili- } \\
\text { ty and place utility. }\end{array}$ \\
\hline \multirow[t]{2}{*}{ Marketing } & wholesalers & $\begin{array}{c}\text { storing potato tuber receive from producer } \\
\text { and collectors in their own store, sorting dam- } \\
\text { aged and deteriorated tubers and finally trans- } \\
\text { porting potato tuber to processors and consum- } \\
\text { ers }\end{array}$ & $\begin{array}{l}\text { Place, time and } \\
\text { possession utility. }\end{array}$ \\
\hline & Local collectors & $\begin{array}{l}\text { assembling, repacking, sorting, transporting po- } \\
\text { tato tuber from surplus to scarce area }\end{array}$ & \\
\hline Processing & Processors & $\begin{array}{l}\text { Transform raw potato to traditional dishes or } \\
\text { "wat", chips (French Fries), crisps }\end{array}$ & $\begin{array}{l}\text { Form, place and pos- } \\
\text { session utility. }\end{array}$ \\
\hline
\end{tabular}

Source: Summary developed by reviewing empirical studies, 2020

An essential part of value chain study is evaluation of performance of given chain. According to Baker et al. (2009) performance measure variables are crucial component in advancing value chain beyond the description and presentation of a value chain into reasoned analysis that allows for identification and analysis of improvements. Lack of consensus on what determined performance of value chain, complicates selection of performance measures (Aramyan, 2006). To determine performance of potato value chain financial perspective of profit sharing was used because most business performance measuring studies used profit as business performance measures (Kaplan and Norton, 1992). Therefore, to determine value chain performance of potato value chain in Ethiopia, percentage monetary value added along the chain and percentage monetary value share by each chain actors were reviewed and comparisons were held. Compared to producers, traders' ${ }^{1}$ operating expense is almost one third (34.9\%) but their profit margin is more than nine tenth of that of farmers. That means by simply buying from the farmers and selling to consumers, traders took $91 \%$ of the total profit margin. While farmers, doing all the work of producing potato and bearing associated risks, took only $9 \%$ of the profit margin. Collectors, wholesalers, and retailers share $23.9 \%, 22.6 \%$ and $44.5 \%$, respectively. The price change from producer's price to consumer price is $110.5 \%$ (Abraham, 2013,). According to Getachew (2015) Compared to farmers, traders' operating expense was around $43 \%$ but their profit margin was around two fold of that of farmers. That means by simply buying from the farmers and selling to consumers, traders took above $65 \%$ of total profit margin, while farmers took only $19.4 \%$ of profit margin. Potato seed tuber producers added $34.03 \%$, while when potato moves from producer to consumers $56.377 \%, 22.315 \%, 15.846 \%$ and $5.462 \%$ of final consumer's price is shared by producers, local traders, wholesalers and retailers, respectively (Tadesse B, et al., 2018). The profit gained by producers, local traders, wholesalers and retailers was 199.125, 483.814, 564.814 and 641.889 birr/qt respectively (Eyasu E and van Beek, 2014; and Abduselam.et.al. 2018)).

${ }^{1}$ In this document "traders" implies for collectors, wholesalers and retailers 


\section{Conclusion and Recommendation}

Potato is among the major root and tuber crops and share $41.14 \%$ of area coverage and $29.9 \%$ of total production. Almost all improved potato varieties released in Ethiopia mature within 124 days, which made potato shorter crop cycle among horticultural crops and is regarded as food security crop in Ethiopian. In Ethiopia potato is commonly consumed in the form of cooked potato in a variety of traditional dishes at household level and also some restaurants and big hotels have French fries on their menu. Each potato consumers have their own quality criteria to purchase potato; prefer medium size potato with smooth skin, fresh, red color and free from any physical damage. To fulfill these consumers preference all chain actors expected to coordinate and collaborate along the chain. Performance of agricultural value chain depends on how well the actors in the value chain are organized and coordinated to capture market focus and consumers demand. The primary actors in a potato value chain are seed and other input suppliers; farmers; traders; brokers; processors; retailers; and consumers. Each of these actors adds value in the process of changing product title; while in Ethiopia potato value chain service providers are Agricultural research centers, agricultural extension service providers offices at different level from ministry to Kebele level office, higher educational institutions, Irrigation development Authority, Trade and market development office, Cooperatives offices, credit and saving institutions and NGOs, but Some service providers extend services beyond one function and others are limited to a specific function.

As a product moves from the producer to the consumer, a number of transformations and transactions take place along a chain and value is added successively at each stage of the chain. Value added may be related to quality, costs, delivery times, delivery flexibility, innovativeness, etc. The size of value added is decided by the end-customer's willingness to pay. Value occurs when needs are met through the provision of products, resources, or services. Performance measure variables are crucial component in advancing value chain beyond the description and presentation of a value chain into reasoned analysis that allows for identification and analysis of improvements. To determine performance analysis of potato value chain in Ethiopia, financial perspective of percentage monetary value added along the chain and percentage monetary value share by each chain actors were reviewed and comparisons were held (margin calculation and distribution). Compared to producer farmers, traders adding low cost margins and sharing market margin and profit margin. In value chain business model, one may share largest along the pie, but it should be win-win and proportionate. In all reviewed potato value chain studies conducted in Ethiopia, disproportionate share of benefits is reflected along the chain. More value adding and risk bearing potato producer farmers and their association are sharing less marketing and profit margin compared to traders and percentage value added.

Based on above review results, the following points were recommended to upgrading potato value chain and develop value chain which could ensure win-win business approach along the chain:

\section{$\checkmark$ Tariff setting and fixing responsibility of brokers:}

The case potato marketing in Ethiopia, brokers do not follow proper business conduct and as a result they constrain the marketing system more than they facilitate, which resulted with traders are price makers at all frame gate transaction. The coupled effect of excess supply and perishable nature of potato obliged producers to sell at prices determined by traders or brokers (Tadesse and Fayera, 2018), which not considers farmers profitability and consumers purchasing power. This may affect sustainability of the chain and reduce trust along the chain. Therefore, tariff setting considering marketing cost added when moving potato from surplus to shortage, production to consumption, which helps to improve bargaining power of all primary chain actors and proportionate value sharing along the chain.

\section{$\checkmark$ Establishing well organized market information system:}

Market Information System is a very important for any commodity exchange and to add value on commodity to work for fulfillment of consumers purchasing criteria and satisfaction of their need. Also market information 
is among things expected to flow along value chain in addition to commodity and currency, study conducted on potato value chain in Ethiopia by Kabeto (2019) shows that farmers have no idea of the price paid by the wholesalers and only receive what has been bargained with the broker. Also brokers sometimes go beyond facilitation of transaction and tend to set prices and make extra benefits from the process which led farmers to add more value when potato moves from producer to end consumer, but share less and disproportionate value. Farmers lack reliable market information and because of this, they were unable to decide or influence the market price. Hence, farmers were price takers to sell their product. Farmers were price takers but traders made margins of potato in the market (Bezabih and Mengistu, 2011) this is because of perishability nature of the commodity. i.e. potato farmers bargaining power become less and less. Therefore, establishment well organized market information helps farmers to work for fulfillment of consumers purchasing criteria from input selection to harvesting, post-harvest handling and marketing as well as it improves proportionate value sharing capacity of farmers.

\section{$\checkmark$ Functional upgrading of producers:}

Functional upgrading is increasing value added by changing the mix of activities conducted within the firm or moving the locus of activities to different links in the value chain. The case of Ethiopia, large proportion of potato was sold in an unprocessed form, but consumers are dependent upon processing for most of their requirements, potato producers were limited only for raw potato production only. Potato value adding reduces post-harvest losses and increases type and volume of outlets may give better prices for the farmers, in particular at harvest time (AgroBIG, 2016). Therefore, upgrading producers function from raw potato production or cultivation to processing helps to reduce perishability and post-harvest loss of the product, while increases income generated from potato.

\section{References}

Abduselam Faris, Zekarias Shumeta and Mequanent Muche. 2018. Value chain analysis of Potato in Dedo district of Jimma zone, Ethiopia. Published at journal of International Journal of Business Management and Technology, 2 (6), 2018, 43-49

Abraham Tegegn. 2013. Value Chain Analysis Of Vegetables: The Case Of Habro And Kombolcha Woredas In Oromia Region, Ethiopia. MSc. Thesis submitted to Haramaya University, Dire Dawa, and Ethiopia.

Adane Hirpa, Miranda P. M. Meuwissen, Agajie Tesfaye, Willemien J. M. Lommen, Alfons Oude Lansink, Admasu Tsegaye \& Paul C. Struik, 2010. Analysis of Seed Potato Systems in Ethiopia. American Journal of Potato Research (2010) 87:537-552.

Addisu Hailu. 2016. Value Chain Analysis Of Vegetables: The Case of Ejere District, West Shoa Zone, Oromia National Regional State Of Ethiopia. Msc. Thesis Submitted To Hramaya University, Dire Dawa, Ethiopia

AgroBIG. 2016. Potato Value Chain Analysis; Programme for Agribusiness Induced Growth in the Amhara region, November, 2016, Bahir Dar, Ethiopia.

Anandajayasekeram, P. and Berhanu Gebremedhin, 2009. Integrating innovation systems perspective and value chain analysis in agricultural research for development: implications and challenges. Improving Productivity and Market Success (IPMS) of Ethiopian farmers project working paper 16. ILRI (International Livestock Research Institute), Nairobi, Kenya.

Andrew Feller, Dan Shunk, \& Tom Callarman. 2006. Value Chains Versus Supply Chains. Accessed from www. bptrends.com

Atetwe Eleen Nyandiwa. 2016. Value Chain Analysis And Performance Of The Kenyan Good Food Company. Msc. Thesis Submitted To School Of Business, University Of Nairobi, Nairobi, Kenya. 
Bezabih Emana and Mengistu Nigussie.2011. Potato Value Chain Analysis and Development in Ethiopia Case of Tigray and SNNP Regions. Report submitted to International Potato Center (CIP-Ethiopia),c/o ILRI, P.O. Box 5689, Addis Ababa Ethiopia

Central Statistical Agency. 2015. Agricultural Sample Survey Report On Private Peasant Holdings, Meher Season Area And Production Of Major Crops2014/ 2015

Central Statistical Agency. 2016. Agricultural Sample Survey Report On Private Peasant Holdings Meher Season Area And Production Of Major Crops2015/ 2016

Central Statistical Agency. 2017. Agricultural Sample Survey Report On Private Peasant Holdings Meher Season Area And Production Of Major Crops2016/ 2017

Central Statistical Agency. 2018. Agricultural Sample Survey Report On Private Peasant Holdings Meher Season Area And Production Of Major Crops 2017 / 2018

Central Statistical Agency. 2019. Agricultural Sample Survey Report On Private Peasant Holdings Meher Season Area And Production Of Major Crops 2018 / 2019

FAO (Food and Agricultural Organization). 2006. Commodity Chain Analysis. On-line Resource Materials for Policy Making. Analytical Tools: Financial Analysis. FAO, Rome, Italy. www.fao.org/docs/up/easypol/331/ CCA_044EN.pdf.

Gereffi, G. and Memedovic, O. (2003) The Global Apparel Value Chain: What Prospects for

Getachew Biru.2015. Analysis of Potato Seed Tuber Value Chain: The Case of Small Scale Farmers In Jeldu District of West Shawa Zone, Oromia, Ethiopia. MSc. Thesis submitted to School of Graduate Studies, Haramaya University, Ethiopia.

Getachew Biru.2015. Analysis of Potato Seed Tuber Value Chain: The Case of Small Scale Farmers In Jeldu District of West Shawa Zone, Oromia, Ethiopia. MSc. Thesis submitted to School of Graduate Studies, Haramaya University, Ethiopia.

Girma Abera, Hailu Gudeta, Mathewos Belissa, Gemechu Shale, Ashenafi Degefe and Bikila Akassa, 2006. Gender Based Roles and Resource Use Wright in Potato Production and Marketing System: The Case of Some District in Oromia, Ethiopia. Bako: Oromia Agricultural Research Institute.

GTZ (German Agency for Technical Cooperation), 2007. Value Links Manual. Eschborn: GTZ.

Habtamu Gebre.2015. Analysis of Potato Value Chain in Hadiya Zone of Ethiopa. MSc. Thesis School of Graduate Studies, Haramaya University, Ethiopia.

Hirpa, A., Mwuwissen, M. P. M., Tesfaye, A. Lommen, W. J. M., Lansink, A. O.,Tsegaye, A., Struick, P. C., 2010, Analysis Of Seed Potato System In Ethiopia, Americal Journal Of Potato Research, Vol. 87 (6), Pp. 537-552

Humphrey, J. 2005. Shaping Value Chains for Development: Global Value Chains in Agribusinesses,GTZ, Eschborn.

Humphrey, J. and O. Memedovic, 2006. Global value chains in the agri-food Sector UNIDO

Humphrey, J., 2003. Opportunities for SMEs in developing countries to upgrade in a global economy. ILO SEED Working Paper No. 43, Geneva.

Jacques H. Trienekens. 20111. Agricultural Value Chains in Developing Countries A Framework for Analysis; International Food and Agribusiness Management Review ;14,(2), 2011. Wageningen University-Management Studies and Maastricht School of Management Hollandseweg 1, Wageningen, The Netherlands

Joshi, R.S. and Gurung, R.B. 2009. Potato in Bhutan -Value Chain Analysis. Regional Agricultural Marketing and Cooperative Office (RAMCO), Mongar the Netherlands Development Programme (SNV), Thimphu, The 
Netherlands.

Kabeto Tadele. 2019. Potato Value Chain Analysis in the case of Dugda Woreda, East Shoa Zone, Oromia National Regional State of Ethiopia. MA thesis submitted to Addis Ababa University School of Commerce, Addis Ababa, Ethiopia.

Kaplan, R. \& Norton, D.1992. The Balanced Scorecard: Measures that Drive Performance.Hbs. edu. Retrieved from http://www.hbs.edu/faculty/Pages/item.aspx?num=9161

Kaplinsky, R. and Morris M. 2000. Globalization and Unequalization: What can be Learned from Value Chain Analysis. Journal of Development Studies, 37(2): 117-146.

Lemaga, B., 2010, The Potato Value Chain in Sub-Saharan Africa with Case Study on Eastern Africa in Strengthening Potato Value Chains, Technical and Policy Options for Developing Countries, FAO Corporate Document Repository, Rome

Lilian Kirimi, Nicholas Sitko, T.S. Jayne, Francis Karin, Milu Muyanga, Megan Sheahan, James Flock, And Gilbert Bor.2011. Farm Gate-To-Consumer Value Chain Analysis Of Kenya's Maize Marketing System. MSU International Development Working Paper No. 111

Raikes, P., M. Jensen, and S. Ponte, 2000. Global commodity chain analysis and the Frencfiliére approach: comparison and critique. Economy and Society, 29 (3): 390-418.

Stevenson, G.W. and Pirog, R. 2013. Values-Based Food Supply Chains: Strategies for Agri-Food Enterprises-ofthe-Middle: UW-Madison Center for Integrated Agricultural Systems and Michigan State University Center for Regional Food Systems, Michigan, USA.

Tadesse B, Fayera B. 2018. Value Chain Analysis of Potato: The Case of Sheka Zone, Southwest Ethiopia. Int J Hort Agric. 3(1): 1-10.

Wondim Awoke and Desselgn Molla. 2018. Value chain analysis of potato: The Case of South Achefer and Jabi Tehinan districts of West Gojam Zone, Ethiopia. Published at Journal of Food and Agricultural Sciences 8(5), 30-38.

Citation: Abayneh Feyso Ergetew, Review of Potato Value Chain Performance in Ethiopia: Financial Value Addition and Margin Sharing Perspective, vol 6, no. 4, 2020, pp. 1-9.

Copyright (C) 2020 Abayneh Feyso Ergetew, This is an open access article distributed under the Creative Commons Attribution License, which permits unrestricted use, distribution, and reproduction in any medium, provided the original work is properly cited. 